\title{
PENERAPAN K3 OLEH PERAWAT DI RS UNTUK MENINGKATKAN NILAI KEPROFESIONALAN BAGI PERAWAT
}

\author{
SRI HARVITA SARI MARPAUNG / 181101125 \\ sriharvitaaasm@gmail.com
}

\begin{abstract}
ABSTRAK
Kecelakaan saat bekerja di RS sangat banyak ditemukan pada saat ini. Salah satu upaya yang dibuat oleh pemerintah untuk meminimalisir kesalahan yang terjadi pada proses kesehatan adalah dengan menerapkan K3. Penulisan ini bertujuan untuk mengetahui dan memberi informasi tentang aplikasi perawat dalam menjalankan K3. Penulisan ini menggunakan metode literature review dengan pendekatan jurnal atau artikel, buku dan $e$-book yang relevan dan akurat serta berfokus tentang aplikasi perawat dalam menjalankan K3 dengan menggunakan Google Scholar, Portal Garuda, dan Jurnal Keperawatan Indonesia. Berdasarkan hasil pencarian literatur di dapatkan bahwa keselamatan pasien dapat berpengaruh terhadap peningkatan mutu pelayanan kesehatan. Oleh sebab itu sebagai tenaga medis harus menerapkan K3 untuk mengurangi resiko kesalahan pada saat melakukan tindakan. Untuk meningkatkan mutu pelayanan dan keselamatan pasien, maka penerapan K3 dapat menjadi salah satu aspek pendukung. Penerapan K3 yang baik dapat meningkatkan citra Rumah Sakit dan juga mutu Pelayanan Kesehatan terutama berpusat pada Keselamatan Pasien dalam proses perawatan atau pengobatannya.
\end{abstract}

Kata kunci : Pelayanan Kesehatan, keselamatan pasien, keselamatan dan kesehatan kerja

\section{LATAR BELAKANG}

Rumah sakit merupakan sarana kesehatan yang menyelenggarakan pelayanan kesehatan, tempat berkumpulnya orang sehat dan sakit. Resiko kemungkinan terjadinya gangguan kesehatan dan penularan penyakit di rumah sakit sangat tinggi. Oleh sebab itu, pemerintah meningkatkan kepeduliannya terhadap masalah Kesehatan dan Keselamatan Kerja (K3) yang dikaitkan dengan isu perlindungan tenaga kerja dan hak asasi manusia serta kepedulian terhadap lingkungan hidup.

Melalui hasil riset, banyak sekali bahaya-bahaya yang ditemukan saat bekerja dirumah sakit, Kasus yang sering terjadi adalah tertusuk jarum, terkilir, tergores, terpotong, luka bakar, penyakit infeksi dan lain-lain.

Dari data tersebut, dapat disimpulkan bahwa potensi bahaya di rumah sakit sangat tinggi. Oleh karena itu, dibutuhkan langkah manajemen untuk mengontrol seluruh tenaga kerja supaya terhindar dari insiden yang tidak diinginkan. 
Penerapan K3 (Keselamatan dan

Kesehatan Kerja) di rumah sakit

menjadi sangat penting dalam rangka

melindungi seluruh pekerja dari

kecelakaan kerja dan penyakit.

\section{TUJUAN}

Tujuan penulisan ini adalah untuk mengetahui dan memberi informasi tentang aplikasi perawat dalam menjalankan K3.

\section{METODE}

Penulisan ini menggunakan metode literature review dengan pendekatan jurnal atau artikel, buku dan e-book yang relevan dan akurat serta berfokus pada aplikasi perawat dalam menjalankan K3. Adapun jurnal atau artikel dan $e$-book yang digunakan pada literature review adalah jurnal atau artikel dan $e$-book yang didapatkan dengan menggunakan Google Scholar, Portal Garuda, dan Jurnal Keperawatan Indonesia.

\section{PEMBAHASAN}

\section{Kesehatan dan Keselamatan Kerja}

K3 merupakan suatu upaya untuk menjamin keutuhan kondisi jasmani dan rohani.dapat diartikan juga sebagai usaha mencegah kemungkinan terjadinya kecelakaan kerja, penyakit akibat kerja yang dapat berdampak pada keselamatan dan kesehatan seseorang. Pelaksanaan Keselamatan dan Kesehatan Kerja (K3) adalah salah satu bentuk upaya untuk menciptakan tempat kerja yang aman dan sehat, sehingga dapat mengurangi resiko kecelakaan kerja. Penerapan K3 di rumah sakit diharapkan mampu memberi pembaharuan terhadap pelayanan kesehatan rumah sakit agar tercipta lebih baik dari sebelumnya. Selain itu , $\mathrm{K} 3$ dapat dijadikan media preventif dan proteksi diri dari penyakit penyakit akibat kerja dan kejadian kejadian yang tidak di inginkan di rumah sakit.

Setiap Rumah Sakit wajib melaksanakan pelayanan kesehatan dan keselamatan kerja sesuai peraturan perundang-undangan yang telah dikeluarkan oleh pemerintah.

Pelaksanaan K3 dapat menjadi gambaran mutu pelayanan yang baik di rumah sakit. Penerapan K3 dapat berjalan baik apabila setiap petugas memiliki keinginan dan kebijakan yang baik dari rumah sakit untuk menerapkannya. Rumah sakit sebagai penyedia sarana harus memberikan pelayanan yang baik tidak hanya untuk pasien, tetapi juga karyawan dan tenaga 
kesehatan di dalamnya. Apabila K3

(Keselamatan dan Kesehatan Kerja) dari

karyawan dan tenaga kesehatan di

rumah sakit diperhatikan, tentu mutu

pelayanan yang akan diberikan

berkualitas.

\section{KESIMPULAN}

Keselamatan dan Kesehatan Pasien

(K3) merupakan aspek terpenting yang

harus diperhatikan oleh petugas Rumah

Sakit. Penerapan K3 yang baik dapat

meningkatkan citra Rumah Sakit dan

juga mutu Pelayanan Kesehatan

terutama berpusat pada Keselamatan

Pasien dalam proses perawatan atau

pengobatannya.

\section{REFERENSI}

Ardi, S. \& Widodo H. (2018). Analisa Penerapan Budaya Perilaku Keselamatan dan Kesehatan Kerja di Rumah Sakit. Jurnal Fakultas Kesehatan Masyarakat. 12(1): 15-20.

Fadhila, N. dkk. (2017). Analisis Upaya Manajemen Rumah Sakit Dalam Penerapan Budaya Kesehatan dan Keselamatan Kerja (K3) Pasca Akreditasi pada Sebuah RSUD di Kabupaten Semarang. Jurnal Manajemen Kesehatan Indonesia. 5(1): 55-61.
Ibrahim, H. dkk. (2017). Gambaran Penerapan Standar Manajemen Keselamatan dan Kesehatan Kerja Rumah Sakit di Rumah Sakit Umum Daerah Haji Makassar. Jurnal Ilmu Kesehatan Masyarakat. 9(2): 160-173.

Ivana, A. dkk. (2014). Analisa Komitmen Manajemen Rumah Sakit (RS) Terhadap Keselamatan Dan Kesehatan Kerja (K3) Pada RS Prima Medika Pemalang. Jurnal Kesehatan Masyarakat. 2(1): 35-41.

Mauliku, N. E. (2011). Kajian Analisis Penerapan Sistem Manajemen K3RS di Rumah Sakit Immanuel Bandung. Jurnal Kesehatan Kartika. 35-47.

Nazirah, R \& Yuswardi. (2017). Perilaku Perawat Dalam Penerapan Manajemen

Kesehatan dan Keselamatan Kerja (K3) di Aceh. Jurnal Idea Nursing. 8(3).

Nurhidayanti, D. (2017). Pengaruh Pelaksaanaan Keselamatan dan Kesehatan Kerja Terhadap Kepuasan Kerja Perawat. JOM FISIP. 4(1): 1-10. 
Putri, S. dkk. (2018). Pelaksanaan Keselamatan dan Kesehatan Kerja Terhadap Kejadian Kecelakaan Kerja Perawat Rumah Sakit. Jurnal Endurance. 3(2): 271-277.

Rahayuningsih, P. W. \& Widodo H. (2011). Penerapan Manajemen Keselamatan dan Kesehatan Kerja (MK3) di Instalasi Gawat Darurat $\quad R S U \quad P K U$ Muhammadiyah Yogyakarta. Jurnal Fakultas Kesehatan Masyarakat. 5(1): 1-67.

Salikunna, N. A. \& Vera D. (2011). Penerapan Sistem Manajemen Kesehatan dan Keselamatan Kerja di Rumah Sakit Bersalin Pertiwi Makassar. Jurnal Biocelebes. 5(1): 31-42.

Salmawati, L. dkk. (2015). Hubungan Penerapan Sistem Manajemen Keselamatan dan Kesehatan Kerja Dengan Motivasi Kerja dan Stres Kerja Pada Perawat di Rumah Sakit Umum Anutapura Palu. Jurnal Manajemen Pelayanan Kesehatan. 18(1): 4-6.

Simamora, R. H. (2019). Buku Ajar Pelaksanaan Identifikasi Pasien. UWAIS: Inspirasi Indonesia 
